\title{
Penggunaan Media Simulasi Phet Untuk Meningkatkan Keterampilan Proses Sains
}

\author{
Ngadinem \\ SMA Negeri 6 Yogyakarta \\ bungadinem98@gmail.com
}

\section{Intisari}

Tujuan penelitian ini adalah untuk mengidentifikasi perkembangan keterampilan proses sains (KPS) peserta didik pada materi gerak parabola dan untuk mengetahui ada tidaknya signifikan peningkatan keterampilan proses sains peserta didik dengan memanfaatkan simulasi PhET model Problem Based Learning (PBL). Penelitian ini dilakukan melalui metode pra-eksperimen dengan desain one group pre-test dan post test. Teknik pengambilan sampel dilakukan secara Cluster Random Sampling (sampel acak kelompok). Responden yang terlibat dalam penelitian ini adalah 24 peserta didik kelas XMIPA7 di SMA N 6 Yogyakarta. Proses pengidentifikasi perkembangan KPS peserta didik dianalisis berdasarkan analisis keuntungan yang dinormalitaskan dan ada tidaknya signifikan peningkatan KPS dianalis uji-T one group pre-test dan post test.

Hasil penelitian ini menunjukkan bahwa keterampilan proses sains peserta didik meningkat sebesar 20\% (rendah) pada keterampilan mengamati, 57\% (sedang) pada keterampilan menarik kesimpulan, 81\% (tinggi) pada keterampilan memprediksi, 27\% (rendah) pada keterampilan komunikasi dan $41 \%$ (sedang) pada keterampilan mengklasifikasi. Berdasarkan hasil analisis uji-T one group pre-test dan post-test diperoleh nilai rata-rata keterampilan proses sains peserta didik meningkat dari 60,00 menjadi 77,29 dengan $\mathrm{N}$-gain 0,43 dan sig* $0.00<0.05$. Hasil ini menunjukkan bahwa penggunaan simulasi PhET model PBL dalam pembelajaran fisika secara keseluruhan dapat membantu meningkatkan keterampilan proses sains peserta didik pada kategori sedang.

Kata kunci: Simulasi PhET, Model PBL dan Keterampilan Proses Sains (KPS)

\section{PENDAHULUAN}

Pendidikan adalah sektor yang strategis dalam upaya mencerdaskan kehidupan bangsa. Sekolah merupakan tempat berlangsungnya pendidikan formal dan tempat untuk memperoleh pendidikan dalam cabang ilmu yang beragam. Fisika merupakan salah satu bagian dari Ilmu Pengetahuan Alam atau dikenal dengan sains. Sains merupakan sebuah proses, karena merupakan suatu rangkaian kegiatan yang terstruktur dan sistematis yang dilakukan untuk menemukan konsep, prinsip dan hukum tentang gejala alam termasuk di dalamnya adalah kemampuan berpikir untuk menyusun dan menemukan konsep-konsep baru. Saat ini, sains dan teknologi berkembang sangat pesat sehingga berdampak pada pengembangan metode dan 
media pembelajaran di dunia pendidikan, khususnya dalam penggunaan komputer dan internet. Sistem pendidikan semakin berfokus pada pembelajaran abad ke 21 yang memberikan gerakan-gerakan pembaharuan pendidikan terutama dalam bidang sains dan matematika. Pembelajaran abad ke 21 menekankan sistem pembelajaran pembaharuan berbasis teknologi, informasi dan komunikasi (TIK).

Permasalahan yang sering dihadapi dalam pembelajaran fisika adalah bahwa siswa belajar fisika hanya dengan mengikuti instruksi dari guru. Proses belajar mengajar di kelas yang menekankan pada hafalan belajar dan terlalu fokus pada konten menyebabkan siswa menghafal pengetahuan yang dipelajari, bukan untuk menganalisa dan mensintesis arti sebenarnya dari pengetahuan. Untuk itu diperlukan sarana dan prasarana yang mendukung kelangsungan proses kegiatan belajar mengajar yang lebih praktis dan efektif. Guru diharapkan dalam pembelajaran tidak hanya menggunakan metode ceramah, tetapi lebih sering menggunakan eksperimen atau demonstrasi dengan simulasi untuk mendukung penjelasan konsep pembelajaran. Hal ini menyebabkan peserta didik kurang memiliki pemahaman mendalam mengenai konsep pembelajaran yang dipelajar. Akibatnya, hal ini mengurangi keterampilan proses sains untuk memecahkan masalah yang rumit.

Dengan demikian, proses pembelajaran yang memungkinkan siswa untuk memiliki keterampilan proses sains untuk memecahkan masalah adalah Problem Based Learning atau PBL, sebuah model pembelajaran yang didasarkan pada teori Konstruktivisme. PBL adalah metode instruksional dimana masalah yang relevan diperkenalkan pada awal siklus instruksi dan digunakan untuk memberikan konteks dan motivasi untuk pembelajaran yang mengikuti (Michael, 2004 dalam Aweke Shishigu Argaw, 2016). Chin dan Chia (2004) mengajukan gagasan lima langkah dalam mengimplementasikan PBL, yang diadaptasi dari Sharan dan Sharan (1989), yang meliputi: (1) Mengidentifikasi masalah yang diteliti (2) mengeksplorasi masalah (3) membimbing siswa dalam melakukan penelitian ilmiah (4) menggabungkan temuan, dan (5) menyajikan temuan, evaluasi oleh guru dan refleksi diri. Kelima tingkatan ini berbasis masalah. Apabila seseorang memiliki kemampuan memecahkan masalah berarti orang tersebut dapat berpikir kritis, logis dan kreatif. (Wan Syafii, 2013) 
Beberapa penelitian menunjukkan bahwa pembelajaran menggunakan media simulasi PhET dapat meningkatkan hasil belajar dan motivasi belajar peserta didik. Bukan hanya itu, pembelajaran yang menggunakan media simulasi PhET dapat memfasilitasi adanya keterbatasan referensi petunjuk praktikum dan alat praktikum materi gerak parabola. Media simulasi PhET merupakan perangkat lunak yang mampu memfasilitasi peserta didik dalam kegiatan pembelajaran.

Berdasarkan uraian diatas penulis merasakan pentingnya menciptakan pembelajaran yang variatif dan memungkinkan adanya penggunaan media yang dapat meningkatkan keterampilan proses sains peserta didik lebih baik. Oleh karena itu penulis melakukan sebuah penelitian yang berjudul "Penggunaan Media Simulasi PhET Model Problem Based Learning $(P B L)$ Untuk Meningkatkan Keterampilan Proses Sains Peserta Didik SMA Negeri 6 Yogyakarta Tahun Pelajaran 2018/2019 Materi Gerak Parabola"

\section{METODE}

Metode yang digunakan dalam penelitian ini adalah penelitian pra-eksperimental. Desain penelitian adalah satu kelompok dengan pre-test dan post-test. Dalam penelitian ini, pada pertemuan awal siswa diberi soal pre-test berupa pertanyaan pilihan ganda yang telah dikembangkan dari setiap aspek indikator keterampilan proses sains. Setelah itu, peserta didik memperoleh pembelajaran dan praktikum dengan menggunakan simulasi PhET model Problem Based Learning. Kemudian, aktivitas terakhir adalah peserta didik diberikan soal post-test. Desain penelitian ditunjukkan pada Gambar 1 sebagai berikut.

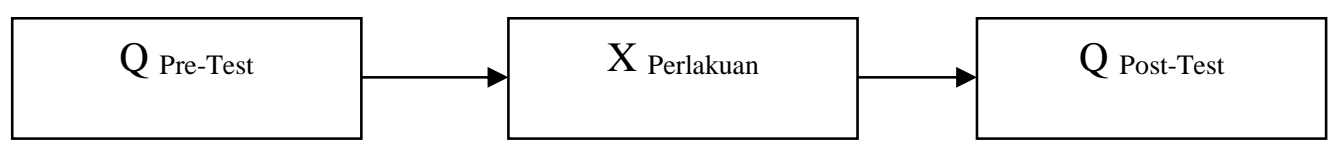

Gambar 1. Desain penelitian satu kelompok pre-test dan post-test

\section{HASIL PENELITIAN DAN PEMBAHASAN}


Data yang diperoleh dalam penelitian ini adalah data kuantitatif hasil pre-test dan posttest dalam bentuk skor tes pilihan ganda. Dengan instrumen penelitian divalidasi oleh seorang seorang guru Fisika SMA Negeri 6 Yogyakarta dan Wakil Kepala Sekolah Urusan Kurikulum dengan hasil validasi bahwa instrument yang digunakan valid. Populasi dalam penelitian ini adalah peserta didik kelas X MIPA SMA Negeri 6 Yogyakarta, yang terdiri dari 222 peserta didik, sedangkan sampelnya adalah kelas X-MIPA7 dengan jumlah 24 peserta didik. Pengolahan data dalam penelitian ini dimulai dengan menghitung nilai pre-test dan post-test. Selanjutnya, nilai pre-test dan post-test dianalisis juga menggunakan uji- T one group pre-test dan post-test menggunakan software SPSS-21. Dengan Hipotesis Ho: jika tidak ada peningkatan keterampilan proses sains dan Ha: terdapat peningkatan keterampilan proses sains. Dengan kriteria pengambilan keputusan jika sig* > 0,05 maka Ho diterima sedangkan jika sig* $<0,05$ maka Ho ditolak. Kemudian, pengaruh penggunaan simulasi PhET model PBL yang diajarkan sebagai keterampilan proses sains peserta didik yang ditentukan dengan menggunakan analisis keuntungan yang dinormalisasi. Perkembangan sebelum dan sesudah pembelajaran simulasi PhET model PBL pada materi gerak parabola dihitung dengan menggunakan persamaan gain normal $<\mathrm{g}>$ sebagai berikut:

$$
\text { Gain normal }(\mathrm{g})=\frac{\text { Nilai post test }- \text { Nilai pre test }}{\text { Nilai } \text { max }- \text { Nilai pre test }}
$$

Dengan kriteria gain dinormalisasi yang disusun oleh Hake dapat dilihat pada Tabel 1.

Tabel. 1. Kriteria gain Normalisasi

\begin{tabular}{ll}
\hline Gain normal $(\mathrm{g})$ & Kriteria \\
\hline$(<\mathrm{g}>) \geq 0.7$ & Tinggi \\
$0.3<(<\mathrm{g}>)<0.7$ & Sedang \\
$(<\mathrm{g}>)<0.3$ & Rendah \\
\hline
\end{tabular}


Data hasil test keterampilan proses sains peserta didik pada materi gerak parabola yang telah diperoleh dianalisis mengguanakan gain untuk melihat selisih nilai post-test dan pre-test. Kemudian untuk mengetahui peningkatannya KPS digunakan rumus N-gain dan nilai signifikan digunakan uji-T one group pre-test dan post-test dengan menggunakan SPSS 21. Rata-rata nilai pretest, posttest, dan nilai sig*, gain, dan $N$-gain dapat dilihat pada Tabel 2.

Tabel.2. Rata-rata Nilai Pretest, Postest, Rata-rata Sig*, Gain, N-gain Kategori

\begin{tabular}{c|c|c|c|c|c|c|c}
\hline $\begin{array}{c}\text { SUMBER } \\
\text { DATA }\end{array}$ & \multicolumn{7}{|c}{ RATA-RATA } \\
\hline \multirow{2}{*}{ KPS } & N & Pre-Test & Pos-Test & Sig* & Gain & N-gain & Kategori \\
& 24 & 60,00 & 77,29 & 0,00 & 17,29 & 0,43 & Sedang \\
\hline
\end{tabular}

*Level signifikan 0,05

Berdasarkan Tabel 2, jika diperhatikan terlihat hasil keterampilan proses sains peserta didik pada materi gerak parabola memiliki rata-rata post-test sebesar 77,29 dengan nilai sig* 0,00. Dikarenakan angka sig* yaitu 0,00<0,05, maka hipotesis Ho secara otomatis ditolak. Hal ini menunjukkan bahwa nilai rata-rata post-test KPS meningkat secara signifikan diatas nilai pre-test sebesar 60,00 dengan skor gain 17,29 dan skor gain ternormalisasi sebesar 0,43 dengan kategori sedang.

Kemudian aspek keterampilan proses sains yang diamati dalam penelitian ini meliputi lima indikator, yaitu keterampilan mengamati, menarik kesimpulan, memprediksi, komunikasi, dan keterampilan mengelompokkan. Pengembangan pada setiap indikator keterampilan proses sains disajikan pada Tabel 3.

Tabel.3. Perkembangan normalisasi gain pada setiap aspek keterampilan proses sains

\begin{tabular}{lcccc}
\hline \multicolumn{5}{c}{ Rata-rata skor } \\
\hline Aspek KPS & Pre-Test & Pos-Test & N-Gain & Kategori \\
Mengamati & 41,67 & 53,13 & 0,20 & Rendah \\
Menarik Kesimpulan & 61,46 & 83,33 & 0,57 & Sedang \\
Memprediksi & 62,50 & 92,71 & 0,81 & Tinggi \\
Mengkomunikasi & 72,92 & 80,21 & 0,27 & Rendah \\
Mengelompokkan & 61,46 & 77,08 & 0,41 & Sedang \\
\hline
\end{tabular}


Hasil perkembangan rata-rata pre-test dan pos-test pada setiap aspek keterampilan proses sains dapat dilihat pada Gambar.2 di bawah ini.

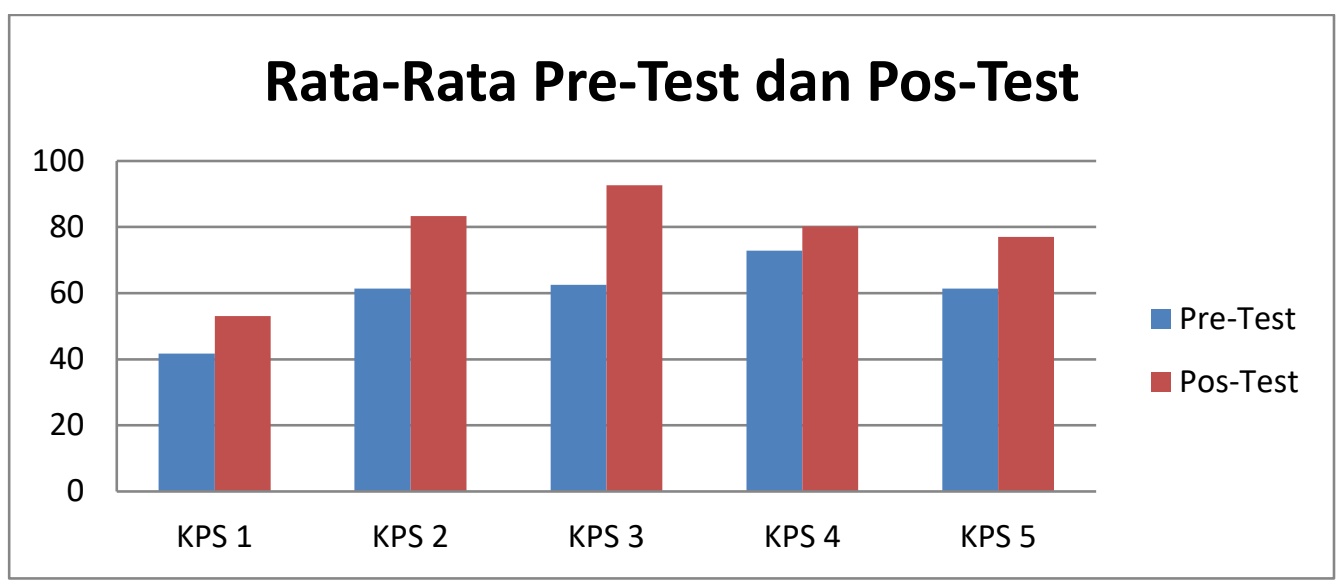

Gambar .2. Grafik perkembangan rata-rata pre-test dan post-test pada setiap aspek keterampilan proses sains.

Hasil Perkembangan nornalisasi gain pada setiap aspek keterampilan proses sains dapat dilihat pada Gambar.3 di bawah ini.

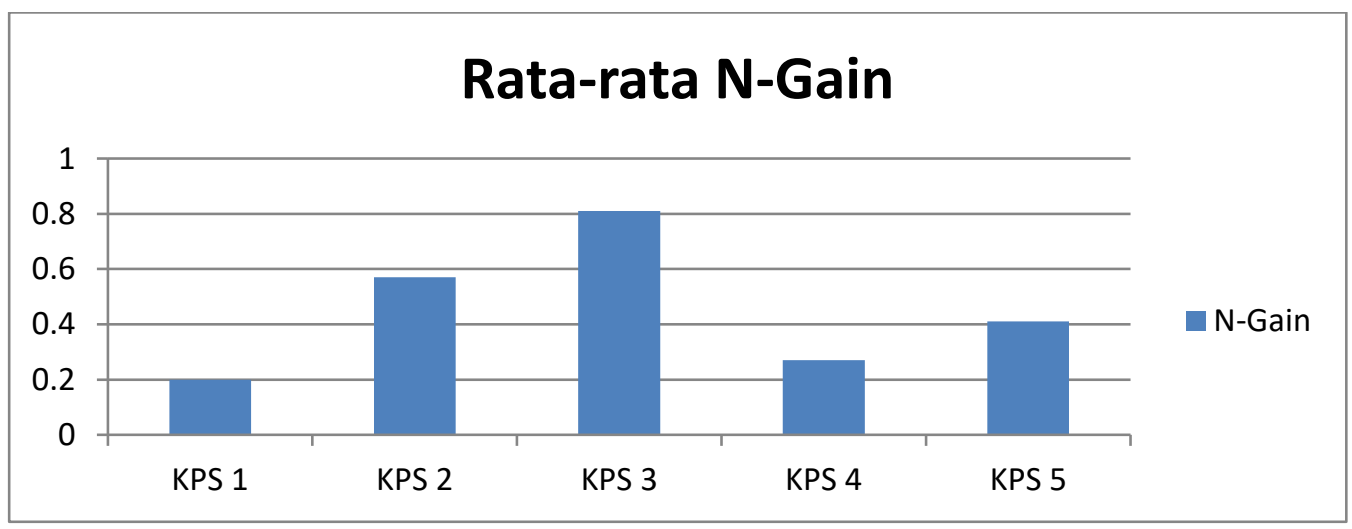

Gambar .3. Grafik perkembangan N-gain pada setiap aspek keterampilan proses sains Keterangan:

KPS 1 : Keterampilan Mengamati

KPS 2 : Keterampilan Menarik Kesimpulan

KPS 3 : Keterampilan Memprediksi 


\section{KPS 4 : Keterampilan Komunikasi}

\section{KPS 5 : Keterampilan Mengelompokkan}

Perkembangan keterampilan proses sains peserta didik untuk setiap aspek indikator KPS, keterampilan memprediksi memiliki skor nilai kenaikan paling signifikan dengan skor $\mathrm{N}$-Gain $(<\mathrm{g}\rangle)$ pada 0,81 . Tetapi di sisi lain, peningkatan terendah terjadi pada keterampilan mengamati $(0,20)$ dan keterampilan komunikasi $(0,27)$ meskipun semua pertanyaan yang dikembangkan untuk kedua aspek ini (masing-masing 4 pertanyaan) berada dalam tingkat kesulitan yang sama yaitu kategori sedang. Selain itu, keterampilan komunikasi merupakan keterampilan yang sering dilatih oleh peserta didik dalam proses pembelajaran. Namun, berdasarkan hasil pengamatan yang dilakukan selama pembelajaran, peserta didik tidak sepenuhnya memahami bagaimana memproses dan menginterpretasikan data, baik dari tabel ke grafik, serta cara mengamati suatu hubungan antara sudut elevasi terhadap waktu yang diperlukan untuk mencapai jarak maksimum yang merupakan salah satu kemampuan yang ada di keterampilan komunikasi dan keterampilan mengamati. Tetapi pada keterampilan memprediksi, peserta didik menguasai keterampilan dalam memecahkan suatu masalah dengan baik. Hal ini karena pendekatan pembelajaran yang diterapkan menggunakan model Problem Based Learning ( PBL ). Jadi, hasil perkembangan keterampilan memprediksi lebih tinggi daripada keterampilan lain karena peserta didik diawali dengan orientasi masalah yaitu pada sudut elevasi berapa benda alan mencapai ketinggian dan jarak maksimum. Berdasarkan hasil penelitian yang diperoleh menunjukkan bahwa penggunaan simulasi PhET model PBL dapat meningkatkan keterampilan proses sains peserta didik.

\section{SIMPULAN}

Berdasarkan hasil penelitian yang telah dilakukan, dapat ditarik suatu kesimpulkan bahwa pengguna simulasi PhET model PBL pada materi gerak parabola untuk peserta didik SMA mampu meningkatkan keterampilan proses sains peserta didik secara signifikan dengan skor gain normal yang dinormalisasi pada materi gerak parabola yang dipelajari. Peningkatan keterampilan proses sains siswa dapat ditemukan di setiap indikator dengan peningkatan tertinggi pada aspek indikator keterampilan memprediksi, sedangkan peningkatan terendah 
terdapat pada aspek indikator keterampilan mengamati dan indikator keterampilan komunikasi. Dengan demikian, penggunaan simulasi PhET model PBL dapat digunakan sebagai alternatif untuk meningkatkan keterampilan proses sains peserta didik. Namun, pada penelitian ini belum dapat meningkatkan keterampilan mengamati dan komunikasi dengan baik. Hal ini didukung oleh hasil penelitian yang menunjukkan bahwa skor gain ternormalisasi masih rendah. Jadi, untuk meningkatkan keterampilan mengamati dan keterampilan komunikasi dapat digunakan media yang mendukung proses pembelajaran untuk mendapatkan pengalaman langsung dengan melakukan eksperimen menggunakan alat nyata. Untuk penelitian lebih lanjut, akan lebih baik jika tes essay untuk mengetahui informasi lebih rinci dari proses berpikir peserta didik dalam menjawab setiap pertanyaan. Selain itu, penilaian kinerja harus dilakukan agar keterampilan tersebut dapat diamati secara langsung dan lebih akurat.

\section{DAFTAR PUSTAKA}

Aweke, SA., Beyene, BH., Beyene, TA., Shiferaw, GK. (2017). The Effect Of Problem Based Learning (PBL) Instruction On Students' Motivation and Problem Solving Skills Of Physics. Eurasia Journal Of Mathematics Science And Technology Education, 13(3) : 857-871. https://dx.doi.org10.12973/eurasia.2017.00647a

Bismarbasa. (2012). Pengertian Pemecahan Masalah. ( $\underline{\text { http://id.shvoong.com/social- }}$ sciences/education/2253033-pengertian-pemecahan-masalah/ Dakses pada tanggal 11 Januari 2013 ).

Chin, C., \& Chia, L. (2004). Implementing project work in biology through: Problem based learning. Journal of Biological Education, 38(2), 69-75. https://dx.doi.org/10.1080/00219266.2004.9655904

Depdikbud. (2016). Permendikbud No. 22. (2016). Tentang Standar Proses Pendidikan Dasar dan Menengah.

Djemari, M. (2012). Pengukuran Penilaian \& Evaluasi Pendidikan. Yogyakarta: Nuha Litera. 
Gunawan, A. Harjono, H. Sahidu1, L. Herayanti. (2017). Virtual Laboratory To Improve Students' Problem-Solving Skills On Electricity Concept. Jurnal Pendidikan IPA Indonesia, 6 (2) : 257-264. https://doi.org/10.15294/jpii.v6i1.8750

Hake R R (1999). Analyzing Change/Gain Scores (Indiana: Indiana University)

Kaniawati, I., Samsudin, A., Hasopa, Y., Sutrisno, A. D., and Suhendi, E. (2016). Journal of Physics: Conference Series, 739

Noppadon Phumeechanya, Panita Wannapiroon. (2014). Design Of Problem-Based With Scaffolding Learning Activities In Ubiquitous Learning Environment To Develop Problem-Solving Skills. Procedia - Social and Behavioral Sciences 116, 48034808.https://dx.doi.org/10.1016/j.sbspro.2014.01.1028

Samsudin, A., Suhandi, A., Rusdiana, D., Kaniawati, I and Coştu, B (2016) . Asia-Pacific Forum on Science Learning and Teaching, 17 (1), 1.

Samsudin, A., Suhandi, A., Rusdiana, D., and Kaniawati, I . (2016). Journal of Physics: Conference Series, 739 .

Sunni, M.A., Wartono, dan Diantoro, M.( 2014). Pengaruh Pembelajaran Problem Solving Berbantuan PhET Terhadap Penguasaan Konsep Fisika Dan Kemampuan Berpikir Kritis Siswa SMA.Malang : Pasca Sarjana MPIPA Universitas Negeri Malang

Wan Syafii, Ruhizan Mohd Yasin. (2013). Problem Solving Skills And Learning Achievements Through Problem-Based Module In Teaching And Learning Biology In High School. Asian Social Science; Vol. 9, No. 12: 220-228 